\title{
Bacteruria Associated Urogenital Infections Amongst Women "a Study On Assymptomatic And Symptomatic Presentation In Benin Metropolis, Nigeria"
}

Ibeh.n.Isaiah

${ }^{1}$ Department of Medical Microbiology, University of Benin Teaching Hospital, PMB 111 ${ }^{2}$ Department of Microbiology, Faculty of Life Science, University Of Benin, PMB 1154

\section{ABSTRACT}

Introduction: Symptomatic and Asymptomatic urinary tract infection in women is of great importance to determine the causal and treatment of bacteruria in young women which may lead to disease states. Aim: to determine the occurrence of asymptomatic bacteriuria in young women and its relationship with urinary tract infection Methods: A microbiological analysis of urine was done on 3600 young women in urban Benin metroplolis from July 2009 to July 2010, a total of 1105 microorganism were isolated from both Symptomatic and Asymptomatic young women. Results: From the 1105 isolates from the descending order of occurrences Escherichia coli, Kleibseilla spp, Enterococcus faecalis and Staphylococcus aureus with Acinobacter spp with the least occurrence. Escherichia coli was the commonest cause of Asymptomatic urinary tract infection with $31.6 \%$ and Acinectobacter sp $9.5 \%$ with the least occurrence of Asymptomatic urinary tract infections. Conclusion: This study shows that there is a rise in asymptomatic urinary tract infection amongst young women in Benin City.

Key Words: Bacterluria, UTI, Asymptomatic
*Correspondence to Author: Email: kroniquegx@yahoo.com, Phone: +2348085843584

How to cite this article:

Ibeh.n.Isaiah. Bacteruria Associated Urogenital Infections Amongst Women "a Study On Assymptomatic And Symptomatic Presentation In Benin Metropolis, Nigeria". American Journal of Microbiology and Immunology, 2016,1:5.

Accepted 24 Auguest 2016; published 24 Auguest 2016.

\section{eSciencePublisher}

eSciPub LLC, Houston, TX USA. Website: http://escipub.com/ 


\section{Introduction}

The quantitative analysis of bacteria in urine cultures was developed several decades ago to establish reliable criteria for discriminating between infection and contamination in asymptomatic subjects, with the expectation that asymptomatic infection might be associated with pyelonephritis, hypertension, renal disease, and complications of pregnancy $[1,4,5,8]$. In studies reviewed, asymptomatic bacteriuria counts of at least $10^{5}$ colony-forming units per milliliter were usually predicted as persistently high levels of bacteriuria, whereas counts of less than $10^{5}$ colony-forming units per milliiter usually meant persistently low levels of bacteriuria with distinctive microflora for each group $[2,4,5]$. Moreover, high concentrations of pathogenic bacteria in serial voided urine specimens had the same predictive value as the presence of bacteria in single catheter specimens $[4,5]$. Therefore, the presence of at least $10^{5}$ colony-forming units of the same urinary tract pathogen per milliliter in consecutive voided urine specimens has been widely adopted as the criterion for identifying potentially important bacteriuria in asymptomatic women $[7,8]$. According to this definition, the prevalence of asymptomatic bacteriuria in healthy women 18 to 40 years of age is approximately 5 percent, and it increases with age to 20 percent or more in ambulatory elderly women.[8-11] Even though asymptomatic bacteriuria is very common and appears to progress with adverse outcomes in some groups, such as pyelonephritis in pregnant women, little is known about its pathogenesis, natural history, risk factors, and temporal association with symptomatic urinary tract infection $[4,7,8,12]$.

\section{Materials and Methods}

Briefly, the study was conducted from July 2009 to July 2010 at the in urban Benin metropolis. The study was approved by the review committees of the institution, and all the women gave written informed consent. Women were eligible for inclusion if they were healthy, were between 18 and 35 years old that have had no history of urinary tract infection in the previous 12 months. Women were ineligible if they were pregnant or planning to become pregnant, had a chronic illness requiring medical supervision, had taken an antimicrobial drug within the previous 14 days, or had a known anatomical or functional abnormality of the urinary tract.
Midstream urine specimens were collected for aerobic bacterial cultures and evaluated microbiologically by previously described methods.

.Asymptomatic bacteriuria was defined by the presence of at least $10^{5}$ colony-forming units of a urinary tract pathogen per milliliter in a culture of a midstream urine specimen obtained from an asymptomatic woman on a routine scheduled visit. An episode of asymptomatic bacteriuria was defined by the presence of either one isolated culture with evidence of asymptomatic bacteriuria or two or more consecutive cultures with evidence of asymptomatic bacteriuria due to the same species. A woman was considered to have a symptomatic urinary tract infection if she had dysuria, urinary frequency, or urinary urgency together with at least $10^{2}$ urinary tract pathogens per milliliter.

In the absence of a urine culture, a woman was considered to have a symptomatic urinary tract infection if she had received a diagnosis of a urinary tract infection from a health care provider or had been treated for urinary symptoms with an antimicrobial drug[13]. Organisms considered as urinary tract pathogens included gram-negative bacilli, Staphylococcus saprophyticus, S. aureus, enterococci, and group B streptococci, alpha-hemolytic streptococci. Lactobacilli, diphtheroids, and mixed gram-positive flora were categorized as non-pathogens.

\section{Results}

A total of three thousand six hundred (3600) samples was collected from three thousand six hundred women who did not show sign of any form of urinary tract infection and their specimen was accessed microbiologically. A total of one thousand one hundred and five (1105) isolates were identified, of these isolates it was noticed that Escherichia coli had the highest occurrence with $31.6 \%$, Klebseilla spp $23.5 \%$, Staphylococcus aureus, $19.0 \%$, Enterococcus faecalis $16.2 \%$ and Acinectobacter spp $9.5 \%$ respectively.

It was noticed that the above women with the highest occurrence of asymptomatic bacteriuria were noticed from the ages of 18- 25 years of age and these young women were also noticed to be sexually active women. Further more these women were broken down into two age groups 18-25 years and 25-35 years, 
Table 1: Occurrence of Bacteriuria and age profile of Asymptomatic females..

\begin{tabular}{llll}
\hline $\begin{array}{l}\text { ORGANISM } \\
(\mathrm{n})=1105\end{array}$ & \%OCCURRENCE & AGE PROFILE (YRS) & PUS CELLS \\
\hline $\begin{array}{l}\text { Escherichia coli } \\
(\mathrm{n})=350 / 1105\end{array}$ & 31.6 & $18-35$ & $>5$ CELLS \\
$\begin{array}{l}\text { Klebseilla spp } \\
(\mathrm{n})=260 / 1105\end{array}$ & 23.5 & $18-30$ & $>5$ CELL \\
$\begin{array}{l}\text { Staphylococcus aureus } \\
(\mathrm{n})=210 / 1105\end{array}$ & 19.0 & $18-30$ & $>5$ CELLS \\
$\begin{array}{l}\text { Enterococcus faecalis } \\
(\mathrm{n})=180 / 1105\end{array}$ & 16.2 & $18-27$ & $>5$ CELLS \\
\hline $\begin{array}{l}\text { Acinectobacter spp } \\
(\mathrm{n})=105 / 1105\end{array}$ & 9.5 & $18-35$ & $>5$ CELLS \\
\hline
\end{tabular}

Table 2: shows the age occurrence of asymptomatic young females

\begin{tabular}{c|c}
\hline AGES $n=1105$ & \% OCCURRENCE \\
\hline $18-25(n)=855 / 1105$ & 77.3 \\
$25-35(n)=250 / 1105$ & 22.6 \\
\hline
\end{tabular}

Table 3: Percentage number of Asymptomatic Bacteriuria and sexually active and inactive women in urban Benin Metropolis

\begin{tabular}{|c|c|}
\hline $\begin{array}{l}\text { \%Number of sexually active women WITH ASYPM- } \\
\text { TOMATIC BACTEURIA } n=1105\end{array}$ & $\%$ ISOLATES \\
\hline $\begin{array}{l}\text { 685/1105, (66.5) } \\
n=685\end{array}$ & $\begin{array}{l}\text { Escherichia coli(250)34.0\%, Klebseilla spp ( } 180) \\
24.4 \% \text { Staphylococcus aureus(115) } 15.6 \% \text {, En- } \\
\text { terococcus faecalis }(110) 14.9 \% \text { Acinectobacter spp } \\
(80) 11.6 \%\end{array}$ \\
\hline $\begin{array}{l}\% \text { NUMBER SEXUALLY INACTIVE WOMEN WITH } \\
\text { ASYMPTOMATIC BACTEURIA } \\
370 / 1105(33.4) \\
\mathrm{n}=370\end{array}$ & $\begin{array}{l}\text { Escherichia coli(100) } 27.0 \% \text {, Klebseilla spp( } 80 \text { ) } \\
21.6 \% \text { Staphylococcus aureus(95) } 25.6 \% \text {, Entero- } \\
\text { coccus faecalis(70) } 18.9 \% \text { Acinectobacter spp (25) } \\
6.7 \%\end{array}$ \\
\hline
\end{tabular}


$30.6 \%$ of asymptomatic women showed presence of one or more bacteria in urine and most of the ladies with asymptomatic infection showed markedly the presence of pyuria in the urine deposit, the pus-cells here were used as marker of infection.

\section{Discussions}

The presence asymptomatic bacteriuria in young females in Benin metropolis has increased, although, these women were either sexually active women or sexually inactive women, there the occurrence proven that $30.6 \%$ of the asymptomatic women showed one or three organism in their urine. These rates of asymptomatic bacteriuria are similar to those described in nonpregnant [8-10] and pregnant women $[5,8]$ but higher than those reported in healthy young school girls [21].

The age prevalence of 18-35 years showed the highest incidence of bacteriuria and this is the sexually active group. Although in this study Escherichia coli has proven to be the most occurred isolates causing asymptomatic bacteriuria in young women.

The use of the clean-voided midstream method of collection and quantitative analysis of urine cultures to differentiate infection from contamination and to delineate the natural history of bacteriuria is well established [3-5]. In these studies, there was an 80 percent likelihood that a voided midstream urine specimen with at least $10^{5}$ gram-negative bacteria per milliliter would be followed by a specimen with a similarly high colony count, and two consecutive voided specimens were therefore needed to provide the same degree of accuracy as a single urine specimen obtained through a catheter in predicting bladder bacteriuria $[4,5]$. This finding that asymptomatic bacteriuria is associated with an increased risk of symptomatic urinary tract infection is in agreement with findings of other investigators [5,6,22,23]. This association was stronger if pyuria was present, suggesting that some episodes of asymptomatic bacteriuria may be early or sub clinical UTI that would eventually lead to the development of symptoms. Further evidence supporting this hypothesis comes from the observation that paired $\mathrm{E}$. coli strains from episodes of asymptomatic bacteriuria and subsequent symptomatic urinary tract infection in a given woman were usually identical if the urine cultures were consecutive, but were usually different if there were one or more intervening negative urine cultures.
There are few other studies with which to compare our data on risk factors. In a case-control study, asymptomatic bacteriuria was associated with diaphragm use but not with sexual intercourse [24]. In the two groups of women we studied prospectively, asymptomatic bacteriuria was associated with the same factors that predispose women to symptomatic urinary tract infection [13] particularly the use of a diaphragm, spermicide and sexual intercourse.

The similarity of risk factors for both asymptomatic bacteriuria and symptomatic urinary tract infection further suggests that E. coli strains that cause asymptomatic bacteriuria and symptomatic urinary tract infection in adult women come from the same pool of fecal strains.

\section{Consent Of Patients}

All work carried out was consented by patients and results were to be published anonymously, without the patients name stated

\section{References}

1. Marple CD. The frequencyand character of urinary tract infections in an unselected group of women. Ann Intern Med 1940;14:2220-39.

2. Kass EH. Asymptomatic infections of the urinary tract. Trans Assoc Am Physicians 1956 ;69:56-64.

3. Merritt AD, Sanford JP. Sterile-voided urine culture: an evaluation in 100 consecutive hospitalized women. J Lab Clin Med 1958;52:463-70.

4. Kass EH. The role of asymptomatic bacteriuria in the pathogenesis of pyelonephritis. In: Quinn EL, Kass $\mathrm{EH}$, eds. Biology of pyelonephritis. Boston: Little, Brown, 1960:399-412.

5. Norden CW, Kass EH. Bacteriuria of pregnancy - a critical appraisal. Annu Rev Med 1968;19:431-70.

6. Kass EH. Bacteriuria and pyelonephritis of pregnancy. Arch Intern Med 1960;105:194-8.

7. Kunin CM. Asymptomatic bacteriuria. Annu Rev Med 1966;17:383- 406.

8. Zhanel GG, Harding GKM, Guay DRP. Asymptomatic bacteriuria: which patients should be treated? Arch Intern Med 1990;150:1389-96 
9. Alwall N. Screening for urinary tract infection in nonpregnant women. Kidney Int 1975;8:Suppl 4:S107-S112.

10. Bengtsson C, Bengtsson U, Bjorkelund C, Lincoln K, Sigurdsson JA.Bacteriuria in a population sample of women: 24-year follow-up study: results from the prospective population-based study of women in Gothenburg, Sweden. Scand J Urol Nephrol 1998;32:284-9.

11. Nicolle LE. Asymptomatic bacteriuria in the elderly. Infect Dis Clin North Am 1997;11:647-62.

12. Mittendorf R, Williams MA, Kass EH. Prevention of preterm delivery and low birth weight associated with asymptomatic bacteriuria. Clin Infect Dis 1992;14:927-32.

13. Hooton TM, Scholes D, Hughes JP, et al. A prospective study of risk factors for symptomatic urinary tract infection in young women. $\mathrm{N}$ Engl $\mathrm{J}$ Med 1996;335:468-74.

14. Counts GW, Stamm WE, McKevitt M, Running K, Holmes KK, Turck M. Treatment of cystitis in women with a single dose of trimethoprim- sulfamethoxazole. Rev Infect Dis 1982;4:484-90.

15. Walker RH. Technical manual. 10th ed. Arlington, Va.: American Association of Blood Banks, 1990.

16. Stapleton A, Moseley S, Stamm WE. Urovirulence determinants in Escherichia coli isolates causing first-episode and recurrent cystitis in women. J Infect Dis 1991;163:773-9.

17. Johnson JR, Russo TA, Brown JJ, Stapleton A. papG alleles of Escherichia coli strains causing first-episode or recurrent acute cystitis in adult women. J Infect Dis 1998;177:97-101.

18. Samadpour M, Grimm LM, Desai B, Alfi D, Ongerth JE, Tarr PI: Molecular epidemiology of Escherichia coli O157:H7 strains by bacteriophage lambda restriction fragment length polymorphism analysis: application to a multistate foodborne outbreak and a daycare center cluster. J Clin Microbiol 1993;31:3179-83.

19. Feinberg AP, Vogelstein B. A technique for radiolabeling DNA restriction endonuclease fragments to high specific activity. Anal Biochem 1983; 132:6-13.

20. Zeger SL, Liang K-Y. Longitudinal data analysis for discrete and continuous outcomes. Biometrics 1986;42:121-30.
21. Kunin CM, Deutscher R, Paquin A Jr. Urinary tract infection in school children: an epidemiologic, clinical and laboratory study. Medicine (Baltimore) 1964:43:91-130.

22. Kunin $\mathrm{CM}$. The natural history of recurrent bacteriuria in schoolgirls. N Engl J Med 1970;282:1443-8.

23. Gaymans R, Haverkorn MJ, Valkenburg HA, Goslings WR. A prospective study of urinary tract infections in a Dutch general practice. Lancet 1976;2:674-7.

24. Strom BL, Collins M, West SL, Kreisberg J, Weller S. Sexual activity, contraceptive use, and other risk factors for symptomatic and asymptomatic bacteriuria: a case-control study. Ann Intern Med 1987;107:816-23.

25. Svanborg C, Godaly G. Bacterial virulence in urinary tract infection. Infect Dis Clin North Am 1997;11:51329.

26. Johnson JR. Virulence factors in Escherichia coli urinary tract infection. Clin Microbiol Rev 1991;4:80-128.

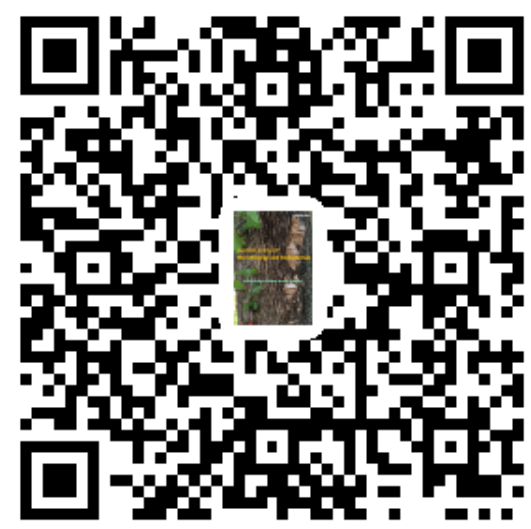

